\title{
Dug put kući - povratak jugoslavenskih iseljenika iz Argentine (1946. - 1951.)
}

\author{
BOJAN SIMIĆ \\ Institut za noviju istoriju Srbije \\ Beograd, Srbija \\ smcbjn@yahoo.com
}

U radu se na temelju arhivskih izvora, stručne literature i onovremenoga tiska analizira povratak jugoslavenskih iseljenika iz Argentine i ostalih dijelova Južne Amerike u prvim godinama nakon Drugoga svjetskog rata. Prati se priprema, organizacija, brojnost, transport, dolazak, smještaj i razmještaj iseljenika u domovini. Analizira se i stručna, nacionalna i spolna pripadnost iseljenika povratnika. Posebna pozornost posvećena je odnosima dviju država, Jugoslavije i Argentine, u ovom pitanju.

Ključne riječi: iseljeništvo; Južna Amerika; Federativna Narodna Republika Jugoslavija; Republika Argentina; repatrijacija

Republika Argentina i Federativna Narodna Republika Jugoslavija (FNRJ) ponovno su uspostavile diplomatske odnose 16. rujna 1946. razmjenom nota između ministra vanjskih poslova Juana Atilija Bramuglia i šefa jugoslavenske diplomatske misije generala Ljube Ilića. ${ }^{1} \mathrm{U}$ prvim poratnim godinama između dvije države postojali su otvoreni problemi, među kojima su se izdvajala pitanja trgovinskih ugovora i razmjene, političke emigracije, problem naknade za nacionaliziranu argentinsku imovinu, pitanje viza za ulazak u Argentinu... Analizirajući više različitih procjena, Ljubomir Antić konstatirao je da se s područja koja su 1918. ušla u Kraljevinu Srba, Hrvata i Slovenaca do Prvoga svjetskog rata u Argentinu uselilo između 25 i 50 tisuća ljudi. ${ }^{2}$ Generalno je zaključak da se s tih prostora masovnije useljavalo tek nakon 1919. godine. Ar-

Ministerio de Relaciones Exteriores, Comercio Internacional y Culto.

ANTIĆ, Naše iseljeništvo u Južnoj Americi, 13. 
gentina je bila država s najviše emigranata podrijetlom iz Jugoslavije u Južnoj Americi. Ondje ih je bilo više nego u svim ostalim državama Južne Amerike zajedno, četiri puta više nego u Čileu. Emigracija nakon Prvoga svjetskog rata mogla se označiti kao klasična ekonomska migracija. Za val koji je pristigao nakon Drugoga svjetskog rata to dobrim dijelom nije bio slučaj. Riječ je o velikom broju pripadnika prije svega ustaške emigracije i manjim dijelom o pripadnicima Jugoslavenske vojske u otadžbini i drugih pokreta koji su iz rata izašli kao poraženi.

General Ljubo Ilić, šef diplomatske misije FNRJ koja je tijekom 1946. boravila na južnoameričkom kontinentu, govorio je o procjeni od 75 do 100 tisuća osoba. On je s potomcima računao na 250 tisuća „argentinskih prijatelja”, a s obiteljima i djecom to bi bilo i do „pola miliona”. Njegov zaključak bio je da je za točan proračun broja jugoslavenskih emigranata neophodan „vrlo veliki rad i mnogobrojno osoblje" ${ }^{3}$

Po podacima do kojih je jugoslavensko poslanstvo u Argentini došlo krajem četrdesetih godina, procjenjivalo se da ima između 60 i 80 tisuća jugoslavenskih iseljenika. Službenici Poslanstva kritizirali su podatke iz iseljeničkoga tiska koji su govorili o većem broju jer su, navodi se, oni računali „i treću generaciju naših iseljenika, koja se potpuno odnarodila". ${ }^{4}$ Inače, jugoslavenski emigranti bili su rasuti duž cijele države. Prema nekim podacima iz 1960., čak 7,7 \% stanovnika Ognjene zemlje bilo je rođeno u Jugoslaviji. Slično je bilo u susjednim provincijama Santa Cruz (5,3 \%) i, nešto sjevernije, Chubut $(4,5 \%) .{ }^{5}$ Broj hrvatskih emigranata u Argentini bio je znatan. Više autora govori o oko 150 tisuća Hrvata u Argentini prije Drugoga svjetskog rata. Talijanski autori Pino i Cingolani, pozivajući se na djelo Iseljena Hrvatska autora Čizmića, Sopte i Šakića, govore o između 130 i 150 tisuća Hrvata u Argentini. ${ }^{6}$ Veći broj navodi i Većeslav Holjevac. ${ }^{7}$

Kad se sve to usporedi sa službenim podacima, nepodudarnost postaje još veća. Prema popisu provedenom 1947. u Argentini, s prostora Jugoslavije u tu zemlju uselila se 46391 osoba, od kojih ju je njih 14870 u određenom trenutku i napustilo. Dakle, prema argentinskim podacima, u njihovoj zemlji boravilo je 31512 osoba podrijetlom iz Jugoslavije. ${ }^{8}$ Razlika između službenih podataka argentinskih vlasti i jugoslavenskih procjena javljala se prije svega zato što

\footnotetext{
3 SR-DAMSP-PA, 1946, Južna Amerika, f. 7, d. 19, s. 13405; SIMIĆ, „Srpska emigracija u Argentini", 56.

4 SR-DAMSP-PA, 1949, Argentina, f. 6, d. 9, s. 49700, „Iseljavanje našeg naroda u Južnu Ameriku”, 2 .

DERADO, ČIZMIĆ, Iseljenici otoka Brača, 211.

PINO, CINGOLANI, Nationalism and Terror, 385.

HOLJEVAC, Hrvati izvan domovine, 184.

IV Censo General del Nacion, Censo de Poblacion, Tomo I, LXII.
} 
su Argentinci polazili od toga da je svatko rođen na njihovu teritoriju njihov državljanin (ius soli). To različito shvaćanje bit će jedan od glavnih izvora razmimoilaženja između predstavnika dviju država i tijekom sljedećih godina.

Važna epizoda vezana za emigraciju iz Južne Amerike, u prvom redu iz Argentine, zbila se krajem četrdesetih godina i vezana je za njihovu repatrijaciju. Naime, samo tijekom 1947. i 1948. vratilo se iz Južne Amerike u Jugoslaviju oko 2600 ljudi, većina iz Argentine. Među povratnicima je bilo najviše građevinskih i tekstilnih radnika, zatim metalaca i zemljoradnika. Ta epizoda zaslužuje veću pozornost ne samo zbog same repatrijacije nego i zbog posljedica koje je imala za odnose dviju država. Ona nam također omogućava da analiziramo socijalnu, spolnu i nacionalnu strukturu povratnika.

Repatrijacija iz Južne Amerike bila je tek dio ukupne repatrijacije u prvim poslijeratnim godinama. Prema podacima koje je prenosio tisak, tijekom 1946. u Jugoslaviju je repatrirano 2000 ljudi, a sljedeće godine taj je broj bio višestruko veći, oko 7000. Najviše ih je bilo iz Francuske (3500), Kanade (1500) i Belgije (500). Broj planiran za 1948. bio je oko 10 000, od kojih je 2000 trebalo stići iz Latinske Amerike. ${ }^{9} \mathrm{Na}$ osnovi ulazne registracije i službenih izvještaja, između 1945. i 1951. u Jugoslaviju se vratilo ukupno 16128 osoba (11 079 muškoga spola, 5049 ženskoga spola). Povratak jugoslavenskih iseljenika u prvim poslijeratnim godinama nije tekao ravnomjerno, a to se može reći i za godine u kojima se događao i za zemlje iz kojih su dolazili. Analizirajući trend povratka, vidi se da se prvih poslijeratnih godina on povećavao, vrhunac je bio 1948. (36,79\% od ukupnoga broja u obrađenom periodu), a u sljedećim je godinama opadao. Trend opadanja bio je vidljiv već u drugoj polovini 1948 . godine. Što se tiče nacionalne strukture povratnika, Hrvati su činili većinu sa $52 \%$, slijedili su Slovenci sa $27,5 \%$, a Srbi su činili $10 \% .^{10}$

Tijekom 1945. za repatrijaciju je bilo zaduženo Ministarstvo za socijalnu politiku, a iduće godine taj posao preuzelo je novoosnovano Ministarstvo rada FNRJ. U Ministarstvu je postojalo Iseljeničko odjeljenje s različitim službama za repatrijaciju, evidenciju, održavanje veza s iseljenicima u inozemstvu i imovinsko-pravnu zaštitu iseljenika povratnika u inozemstvu. Tijekom godina, u skladu s potrebom, to je odjeljenje često mijenjalo strukturu, a 1950. ukinuto je kao poseban organ.

Najave moguće repatrijacije iz Južne Amerike pojavile su se 1946., kada je „Slobodna Jugoslavija”, najveće društvo iseljenika u Argentini, u pismu veleposlanstvu FNRJ u Londonu tražila odobrenje za povratak nekih iseljenika jugoslavenskim trgovačkim brodovima koji budu dolazili u argentinske vode.

\footnotetext{
„Povratak iseljenika u otadžbinu”, Politika (Beograd), 15. 4. 1948., 2.

ŠEGVIĆ, Povratak jugoslovenske ekonomske emigracije, 14-19.
} 
Predsjednik društva Ante Paparela tražio je i ekskluzivno pravo odlučivanja tko se može koristiti tom povlasticom na temelju „zasluga pojedinaca koje udruženje ima u vidu”. U pismu se navode i neka imena zaslužnih pojedinaca. ${ }^{11}$ Ministarstvo rada FNRJ podržalo je krajem kolovoza njihov stav i naglasilo potrebu za što skorijim uspostavljanjem predstavništva u Argentini, što se, vidjeli smo, i dogodilo sljedećega mjeseca. Time je konačna odluka o izboru povratnika prenesena na Poslanstvo.

Već je 1947. bilo govora o organiziranom brodskom transportu iseljenika iz Argentine koji to žele natrag u Jugoslaviju. Prema informacijama koje je imalo Poslanstvo u Buenos Airesu, najviše zainteresiranih bilo je iz Argentine i Urugvaja. Radilo se pretežno o siromašnim radnicima koji su izrazili želju „da daju svoj doprinos u izgradnji i obnovi naše domovine”. Što se tiče imućnijih iseljenika, vlasnika i zakupaca poljoprivrednih imanja, primijećeno je da nisu pokazali veći interes za repatrijaciju i da su izjavljivali da „žele da vide kako će se razviti situacija u Jugoslaviji”. ${ }^{2}$ Na takav stav dijelom je utjecala i neizvjesnost vezana za konverziju kapitala stečenog u Argentini.

Za repatrijaciju iseljenika iz prekooceanskih zemalja jugoslavenska država nabavila je dva parobroda: „Radnik” je kupljen u San Franciscu, a „Partizanka” u Lisabonu; taj je brod prethodno služio za promet između Sjeverne i Južne Amerike, a tijekom rata bio je i brod bolnica američke vojske. „Partizanka” je predana na korištenje poduzeću „Jugolinija” iz Rijeke. ${ }^{13} \mathrm{U}$ sljedećih nekoliko godina oni će za potrebe FNRJ ploviti od Sjeverne i Južne Amerike do Australije. $^{14}$

Problem sa samom organizacijom repatrijacije bio je u tome što se morala odvijati tajno jer je bilo jasno da argentinske vlasti neće s odobravanjem gledati na odvođenje radne snage iz svoje zemlje. To je bilo jasno prije svega zato što je

\footnotetext{
11 SR-AJ-25-66, Pismo udruženja „Slobodna Jugoslavija” ambasadi FNRJ u Londonu od 15. 7. 1946.

12 SR-AJ-25-66, „Izvještaj o pripremanju repatrijacije jugosl. iseljenika iz Argentine i Urugvaja” od 17. 7. 1947., 1-2.

13 Slavko SUZIĆ, „Emigrantski brod Partizanka”, Sušačka revija (Sušak), 2008., br. 60, 23. Pored „Partizanke” i „Radnika” kupljeni su do 1949. i brodovi „Lošinj”, „Bosna”, „Vis”, „Šabac”, „Hrvatska”, „Topusko” i tanker „Jajce”. Borba (Beograd), 5. 8. 1949., 3.

14 O jednom od brodova nalazimo sljedeći opis: „Brod Partizanka imao je pet paluba. Bio je opremljen radarom, žirokompasom, električnim ehosonderom, najmodernijom telegrafijom i telefonijom, aparaturom za otkrivanje požara, napravom za gašenje požara pomoću plina, dok su se sva vrata na nepromočivim pregradama zatvarali automatski sa komandnog mosta. Brod je bio vrlo luksuzno opremljen. Na brodu je bila kino dvorana, knjižnica, čitaonica, nekoliko salona za ples, frizerski i pedikirski salon, brijačnica itd. Brod Partizanka imao je 9900 bt, a bio je pogonjen sa četiri turbine, koje razvijaju 8500 ks. Pokretala su ga dva vijka, a kretao se brzinom od 20 čvorova. Za proizvodnju el. energije imao je četiri generatora koji razvijaju $700 \mathrm{kw}$. Dnevna potrošnja bila je 106 tona nafte.” Citirano prema: Slavko SUZIĆ, „Emigrantski brod Partizanka”, Sušačka revija, 2008., br. 60, 24 .
} 
dio iseljenika dobio argentinsko državljanstvo, što je bio jedan od uvjeta za dobivanje namještenja u raznim državnim poduzećima i državnoj službi uopće. Zato je u ožujku 1947. u Buenos Airesu formirana Komisija za pomoć obnovi Jugoslavije, koja je pored osnovnoga zadatka imala i dužnost baviti se repatrijacijom stručnih radnika. ${ }^{15}$ Cilj te komisije bio je prikupljati podatke o iseljenicima, potencijalnim povratnicima, te širiti propagandu među iseljeništvom radi prikupljanja pola milijuna pesosa za organiziranje posebnih predavanja i konferencija da bi se oni upoznali s aktualnim stanjem u Jugoslaviji. Tu se u prvom redu mislilo na političku i privrednu strukturu zemlje, petogodišnji plan te radničko i socijalno zakonodavstvo FNRJ.

Komisija je pristupila organizaciji grupa radnika po strukama. U kraćem roku organizirane su grupe građevinskih, tekstilnih i metalskih radnika, kao i grupa koja je okupljala one koji nisu spadali ni u jednu od tih grupa. U grupe su ulazili radnici prije svega iz Buenos Airesa i okolice. Sastav je bio sljedeći: a) Grupa građevinskih radnika - 257 osoba (146 muškaraca, 58 žena i 53 djece); b) Grupa tekstilnih radnika - 86 osoba (39 muškaraca, 23 žene i 24 djece); c) Grupa metalskih radnika - 139 osoba (72 muškarca, 28 žena i 39 djece) i d) Grupa raznih struka - 122 osobe (63 muškarca, 35 žena i 24 djece). ${ }^{16} \mathrm{Iz}$ priložene statistike vidi se da je oko polovice prijavljenih radnika bilo u dobi između 35 i 45 godina. Uz prijave koje su iseljenici uputili izravno Poslanstvu možemo konstatirati da je sredinom 1947. iz Argentine bilo prijavljeno ukupno 879 potencijalnih povratnika, od čega 506 muškaraca, 191 žena i 182 djece. ${ }^{17}$

Zapažanje Poslanstva bilo je da repatrijacija ne bi mogla doći u obzir u zimskim mjesecima, što je po njihovu mišljenju obuhvaćalo razdoblje od rujna do veljače, ,jer se većina povratnika boji da stigne zimi u domovinu”. Glavni problemi bili su pitanje prijevoza, odnosno angažiranja broda, kao i plaćanje prijevoznih troškova s obzirom na to da se radilo o ljudima koji „zarađuju jedva toliko da mogu da životare i nisu u mogućnosti da si uštede sredstva za putovanje"..$^{18}$ Odgovornost da odredi tko je od putnika i koliku vrijednost karte sposoban platiti pala je na Poslanstvo. Socijalni ataše Dalibor Soldatić

\footnotetext{
15 Sastav Komisije sredinom 1947. bio je sljedeći: predsjednik Borislav Đukić, inženjer kemije; potpredsjednik Ilija Drašković, trgovac; tajnik Santijago Bošić, građevinski predradnik; zamjenik tajnika Frano Mohorčić, student, metalski radnik; zapisničar Duko Stekar, student; blagajnik Ivan Marinković, vlasnik mehaničarske radnje; odbornici: kamenoklesar Antun Zanetić, vlasnik mehaničarske radnje Frano Valgoni, pekar Antun Sardelić, građevinski poduzetnik Franjo Stekar, vlasnik tiskare Franjo Vider i trgovac Stošić, čije ime nije navedeno. SR-AJ-25-66, „Izvještaj o pripremanju repatrijacije jugosl. iseljenika iz Argentine i Urugvaja” od 17. 7. 1947., 3.

16 Isto, 4-5.

17 Isto, 6.

18 U izvještaju se kaže da je prosječna zarada radnika oko 260 argentinskih pesosa mjesečno, iz čega proizlazi da „ne mogu da uštede ništa”. Isto, 7-8.
} 
predlagao je da država preuzme kompletan trošak prijevoza imajući u vidu težak ekonomski položaj povratnika, ali taj prijedlog nije prošao. ${ }^{19}$

U uputi pomoćnika ministra vanjskih poslova Vladimira Velebita Poslanstvu u Argentini dane su instrukcije što se od njih očekuje. Radilo se o predaji točnih popisa povratnika i članova njihovih obitelji koji će putovati. Posebno je naglašeno da se ne šalju „neradni špekulanti” i oni koji su „nesposobni za koristan rad”. ${ }^{20}$ Velebit je u spomenutom telegramu najavio mogući dolazak prvoga parobroda tek za veljaču 1948. godine.

I u Jugoslaviji se pripremalo za prihvat iseljenika iz Južne Amerike. Već u prvoj godini nakon rata napravljena su prihvatilišta u Splitu, Sušaku, Jesenicama, Kamniku i Zagrebu. ${ }^{21}$ U Splitu su izgrađene drvene barake u Smiljanićevoj ulici, na periferiji grada, kamo su povratnici smješteni, a Splićani su ih zvali „Drveni Čikago” ili „Amerikanske barake”.22 Osnovan je koordinacijski odbor u koji su ušli predstavnici Savezne planske komisije, privrednih resora Savezne vlade i Glavnoga odbora Jedinstvenih sindikata. ${ }^{23}$ Svaka republika pristupila je formiranju specijalnih komisija po kotarevima kamo su pristizali iseljenici. Dužnost komisija bila je brinuti se o smještaju tih ljudi, zaposlenju, školovanju djece i slično. Najagilnija je bila Narodna Republika (NR) Slovenija, u kojoj su već početkom travnja 1948. formirane komisije u šesnaest kotareva, a ostalo je da se formiraju u preostala tri. ${ }^{24}$ Savezna planska komisija odobrila je gradnju drvenih stambenih kuća za povratnike za 400 obitelji. Za izgradnju tih stambenih objekata izdvojeno je 153 milijuna dinara, od kojih je u skladu s potrebom najviše bilo namijenjeno za NR Hrvatsku (76,5 milijuna) i NR Sloveniju (45,9 milijuna). ${ }^{25}$ Generalno, problem stanovanja bio je jedan od najvažnijih s kojim su se susretali iseljenici povratnici i na to su imali najviše pritužbi.

Na temelju pristiglih popisa, a vodeći se postotkom ljudi s područja određenih republika, početkom veljače 1948. napravljen je plan njihova razmještaja. Tako je prema njemu 55 \% kuća trebalo napraviti na teritoriju Hrvatske, $25 \%$ u Sloveniji, $10 \%$ u Bosni i Hercegovini, a preostalih $10 \%$ otpadalo je na Srbiju. U Hrvatsku su razmješteni u prvom redu rudari, pomorci, vinari,

\footnotetext{
19 SR-DAMSP-PA, 1948, Argentina, f. 19, d. 28, s. 432236, „Naši iseljenici u Latinskoj Americi” od 20. 9. 1947., 5.

20 SR-AJ-25-66, Telegram Vladimira Velebita upućen Poslanstvu FNRJ u Buenos Airesu, bez datuma.

${ }_{21}$ Tisak je pisao da je do druge polovine 1948. kroz iseljeničku bazu u Mekinjama kod Kamnika prošlo 5200 iseljenika, od kojih je 75 \% bilo s teritorija NR Slovenije. „Naši iseljenici-povratnici aktivno učestvuju u izgradnji svoje socijalističke domovine”, Politika, 20. 11. 1948., 5.

22 KARAKAŠ OBRADOV, Novi mozaici nacija, 111.

23 ŠEGVIĆ, Povratak jugoslovenske ekonomske emigracije, 24.

24 „Povratak iseljenika u otadžbinu”, Politika, 15. 4. 1948., 2.

25 ŠEGVIĆ, Povratak jugoslovenske ekonomske emigracije, 40.
} 
ribari, industrijski i tekstilni radnici, u Srbiji je planiran razmještaj industrijskih radnika, i to u „Ikarus”, „Rakovicu”, „Železnik” i Novi Sad, a manji broj poljoprivrednih radnika predviđen je za Čoku. ${ }^{26}$ Prema podacima iz ulazne registracije, 7955 iseljenika povratnika od 1945. do 1951. tražilo je smještaj na teritoriju NR Hrvatske, 4596 u NR Sloveniji, a nešto manji broj (1905) kao odredište je imao NR Srbiju. ${ }^{27}$ Naravno, ti se brojevi ne mogu smatrati konačnima jer je dolazilo do promjene prebivališta iseljenika, pa se događalo da neki od njih promijene republiku u kojoj su živjeli.

Radi upoznavanja sa stanjem u Jugoslaviji prije njihova povratka „Slobodna Jugoslavija" organizirala je razna predavanja čije su teme bile povijest Narodnooslobodilačke borbe, ekonomska struktura nove Jugoslavije, organizacija vlasti i sindikata itd. Slične aktivnosti organizirao je i „Slovenski ljudski dom” u Buenos Airesu. Zabilježena je spremnost iseljenika da doprinesu „ostvarenju zadataka iz Petogodišnjeg plana” usprkos „reakcionarnoj propagandi koja se vodi u nekim zemljama Latinske Amerike protiv nove Jugoslavije”. ${ }^{28}$

Sve aktivnosti koje su se poduzimale vezano za repatrijaciju nisu mogle proći bez reakcija argentinskih vlasti. France Pirc, prvi poslanik FNRJ u Argentini, pisao je po povratku iz Jugoslavije da je naišao na prividnu susretljivost, ali je u suštini vladalo nepovjerenje. Primijećeno je da njega i službenike Poslanstva prati argentinska policija, doduše „vrlo neprimjetno i obazrivo ali dosljedno”. Pircov je dojam da se „po svaku cenu” traže dokazi o ilegalnom radu i propagandi. Informacije koje je imao govorile su o tome da policija intenzivno ispituje zašto među jugoslavenskim iseljenicima postoji „velika akcija za repatrijacijom". Sve to navelo ga je na zaključak da se mogu očekivati „teškoće” od argentinskih vlasti u tom pogledu. Pirc je smatrao da treba požuriti s dolaskom broda u Buenos Aires, plašeći se odustajanja iseljenika pod pritiskom. U prilog svojoj tvrdnji iznio je i to da su na primanje povodom 29. studenog koje je organizirao došli samo zastupnik ministra vanjskih poslova i šef policije premda su bili uredno pozvani predstavnici svih ministarstava i svi viši državni dužnosnici. ${ }^{29}$

$S$ obzirom na to da cjelokupna organizacija repatrijacije nije išla ni brzo ni lako, prema podacima Poslanstva FNRJ, oko 450 iseljenika iz Argentine i Urugvaja odlučilo se vratiti u domovinu u vlastitoj režiji. Službeni podaci po-

\footnotetext{
26 SR-AJ-25-66, „Gradnja stanova za iseljenike povratnike” od 2. 2. 1948. Plan je pravljen na osnovi popisa 785 iseljenika s obiteljima.

27 ŠEGVIĆ, Povratak jugoslovenske ekonomske emigracije, 32.

28 „Prva grupa naših iseljenika iz Latinske Amerike vraća se u otadžbinu”, Politika, 8. 4. 1948., 5.

29 SR-AJ-836-KMJ, I-3-b/57, Šifrirano pismo iz Buenos Airesa upućeno Ministarstvu vanjskih poslova od 16. 12. 1947. U kasnijim dokumentima predstavnici FNRJ u Argentini spominju da su čak postojali policijski dosjei jugoslavenskih iseljenika u kojima je pisalo da su bili umiješani u posao oko repatrijacije.
} 
kazuju da je taj broj ipak bio nešto manji: navodi se 178 iseljenika iz Argentine i 131 iz ostalih zemalja. ${ }^{30}$ Nakon dužih priprema prvi transport „Partizankom” krenuo je iz Buenos Airesa 6. travnja 1948. i u njemu je bilo 717 iseljenika, od čega 622 iz Argentine i 95 iz Urugvaja. ${ }^{31}$ Putnu kartu u vrijednosti od 800 argentinskih pesosa platila su 144 putnika, a kartu za drugu klasu u vrijednosti od 600 pesosa 233 putnika. Kupljeno je i osam dječjih karata u pola cijene za prvu klasu te 21 za drugu. Poslanstvo je odobrilo i 125 besplatnih karata za siromašne povratnike. ${ }^{32}$

Treba reći da se popis stvarno otputovalih i onih prije prijavljenih znatno razlikovao. Naime, prije putovanja 52 iseljenika su odustala, a 12 ih se jednostavno nije pojavilo na ukrcavanju. Poslanstvo je umjesto njih naknadno osiguralo još 28 putnika iz Argentine i dva iz Urugvaja. Od stvarno otputovalih najviše je bilo građevinskih radnika (155), metalskih radnika (75), zemljoradnika (39) i tekstilaca (30). ${ }^{33}$ Kao razloge za odustajanje iseljenici su iznosili nemogućnost da na vrijeme prodaju svoje nekretnine, naplatu već obavljenih poslova, prije preuzete obveze i bolest. Poslanstvo je mnoge od tih zahtjeva smatralo opravdanima jer se većina spomenutih iseljenika prijavila za drugi transport. Brod je kasnio u polasku i zbog toga što je angažirana agencija Wilson Sons prvi put organizirala jedan putnički transport.

Nacionalna struktura povratnika iz prvoga transporta prema podacima koji su dostavljeni tisku bila je sljedeća: „486 Hrvata, 107 Slovenaca, 44 Srba, 32 Makedonca, 27 Crnogoraca i 21 iz Bosne i Hercegovine”, a ostalo su činili stranci, Talijani, Ukrajinci, Mađari i stanovnici Čehoslovačke. ${ }^{34} \mathrm{U}$ posebnom pismu poslanik Pirc obratio se Ministarstvu rada FNRJ ističući šest iseljenika koji dolaze i na koje bi trebalo posebno obratiti pozornost prilikom njihova rasporeda na dužnost koju će obavljati u Jugoslaviji jer „od toga kako će oni biti prihvaćeni zavisi dolazak drugih stručnjaka”. Na popisu su bili doktor Ivo Damjanović Dukić, za koga se preporučivalo mjesto na Sveučilišnoj klinici u Zagrebu, inženjer Eduard Bonjolo, pomorski kapetan Drago Leontić, veterinar Radoslav Razmilić-Vlahović, koji su se svi stavljali na raspolaganje jugoslavenskim vlastima. Na popisu su bili i Ljubenko Sasunić, koji je dobio stipendiju za studij elektrotehnike na Zagrebačkom sveučilištu, kao i novinar Ivan Borić, za koga se tvrdilo da je „dosta sposoban” i „vlada perfektno španskim jezikom”, a

\footnotetext{
30 ŠEGVIĆ, Povratak jugoslovenske ekonomske emigracije, 16.

31 SR-DAMSP-PA, 1949, Argentina, f. 6, d. 9, s. 49700, „Referat o jugoslovenskim iseljenicima u Južnoj Americi”, 16-17.

32 SR-AJ-25-66, „Prvi transport iseljenika-povratnika iz Argentine i Urugvaja” od 6. 4. 1948., 2. 33 Isto.

34 „Bivši iseljenici u Južnoj Americi o svome teškom životu u tuđini i radu reakcionarnih krugova”, Politika, 7. 5. 1948., 4.
} 
i dobro poznaje iseljeničke prilike u Južnoj Americi. Borić je preporučivan za redakciju Slobodne Dalmacije. ${ }^{35}$

„Partizanka” je doplovila u Split 24. travnja. Organizirano su ju dočekali predstavnici vlasti i Jugoslavenske armije, kao i građani. Obratili su im se ministar rada NR Hrvatske Alojz Valečić i Ante Peranić ispred Gradskoga odbora Narodne fronte Splita. Uime iseljenika govorio je Drago Leontić, koji je naglasio da će iseljenici uložiti „sve snage za obnovu i izgradnju zemlje i ostvarenje Petogodišnjeg plana”. ${ }^{36}$ Inače, spominjanje rada na zadacima iz toga plana bilo je opće mjesto u gotovo svim obraćanjima i izjavama iseljenika, kao i predstavnika nove vlasti u Jugoslaviji. Doček povratnicima priređen je i u Resenu u Makedoniji, gdje je iseljenik Nikola Kočkovski izjavio da će zajedno s narodom "raditi na ispunjenju Petogodišnjeg plana, za sretniji i bolji život”. ${ }^{37}$ Od iseljenika su uzimane izjave koje je objavljivao tisak, a pored spremnosti da pomognu isticali su i težak položaj radničke klase u zemljama Amerike iz kojih su dolazili.

Prilikom dolaska u Jugoslaviju bilo je predviđeno da iseljenici povratnici provedu između tri i deset dana u prihvatnim centrima radi ulazne registracije i određivanja budućega mjesta boravka. Nakon toga odlazili su na izabrana odredišta. Predstavnici vlasti FNRJ trudili su se pratiti kako se iseljenici uklapaju u nove radne sredine. Tako vidimo da je iz prvoga transporta na gradilištu na Novom Beogradu bilo osam povratnika, od kojih su dvojica bila s obiteljima, a ostali su bili samci. U izvještaju se kaže da su povratnici smješteni u ,jednu vrlo dobru” stambenu baraku. Hranili su se zajedno s omladincima koji su radili na istom gradilištu. U razgovoru s iseljenicima primijećeno je da im nedostaju cigarete, kojih nije bilo u blizini, tisak na latinici jer ćirilicu nisu znali, tuš u blizini, kao i poštanski sandučić. Nadležni službenici izrazili su spremnost da se tražene stvari riješe u najkraćem roku jer se predviđalo da iz sljedećega transporta na isto gradilište dođu još 54 radnika s tridesetak članova obitelji. Suradnja s iseljenicima povratnicima u tom konkretnom slučaju uključivala je i razmatranje njihovih prijedloga vezano za samo izvođenje građevinskih radova, kao što su bolja organizacija rada i smanjenje potrošnje materijala. ${ }^{38}$ Naravno, situacija s povratnicima nije bila idealna. Ministarstvo rada NR Hrvatske zabilježilo je žalbu povratnika Petra Antunovića, koji je radio kao tovitelj svinja u Vojnoj ergeli „Ovčare” - Ivandvor, kotar Slavonska

\footnotetext{
35 SR-AJ-25-66, Pismo poslanika u Buenos Airesu France Pirca upućeno Ministarstvu rada FNRJ od 5. 4. 1948.

36 „Grupa iseljenika iz Južne Amerike doputovala juče u Split”, Politika, 25. 4. 1948., 4.

37 „Svečan doček iseljenika iz Argentine u Resnu”, Politika, 6. 5. 1948., 4.

38 SR-AJ-25-66, „Izveštaj sa obilaska povratnika iz Argentine na gradilištu Novog Beograda u subotu 8. V. $1948 \mathrm{~g}$ ".
} 
Požega. ${ }^{39}$ Antunović se žalio na teške radne uvjete i tražio da ga se rasporedi na drugo radno mjesto jer je „za rad nesposoban 50 \% na nogama”. Savezni inspektor rada zahtijevao je da se taj slučaj riješi u kratkom roku. ${ }^{40}$

Zanimljivo je spomenuti da ni mornarima koji su putovali po iseljenike nije bilo dopušteno „gubiti vrijeme” tijekom dugoga puta. Za njih je organiziran intenzivan kulturno-prosvjetni rad. Pored rada na političkim temama, gdje su se proučavali referati 2. kongresa Narodne fronte Jugoslavije, referat Ždanova o međunarodnoj situaciji i članci Edvarda Kardelja, organizirana je folklorna grupa, kao i zbor. ${ }^{41}$ Naravno, sve se to nastavljalo i nakon ukrcavanja iseljenika i tijekom povratnoga putovanja.

Dok su se privodili kraju poslovi oko prvoga transporta, drugi je već bio popunjen. I u tom slučaju popis putnika znatno se razlikovao od prvobitnoga popisa koji je uputilo Poslanstvo. Opet se radilo o odustajanju u posljednjem trenutku i popunjavanju iseljenicima koji nisu bili na popisu. Ipak, broj odustalih bio je mnogo veći od onih koji su ih zamijenili na brodu (za Argentinu 83 odustalih i 14 novoprimljenih). Zbog svega toga na brod su primani i strani državljani koji su platili prijevoz do Jugoslavije, među kojima je bilo Bugara, Mađara, Albanaca i drugih. No broj putnika bio je bitno manji u odnosu na prethodni. Drugi transport „Partizankom” krenuo je 30. svibnja 1948. u 16 sati i njime je u Jugoslaviju otputovalo 543 putnika iz Argentine. Brod je svratio i do Montevidea, gdje se ukrcalo još 42 iseljenika. Ukupno se radilo o 584 osoba, od kojih je bilo 522 iseljenika i 62 stranih državljana s plaćenim kartama. ${ }^{42} \mathrm{O}$ ispraćaju „Partizanke” u Buenos Airesu pisao je i jugoslavenski tisak. Politika tvrdi da se okupilo oko 15000 Jugoslavena iz svih krajeva zemlje i da je prisutna masa poklicima i pjesmom iskazivala „privrženost i ljubav naših iseljenika u Argentini prema Jugoslaviji i maršalu Titu”. ${ }^{43}$ List se pozivao na pisanje Jugoslavenskoga iseljeničkog vjesnika iz Buenos Airesa, koji je s ispraćaja dao opširan prikaz s fotografijama.

Neposredno prije odlaska drugoga transporta pojavila se vijest o uhićenju povratnika Srećka Turela, koji je živio u blizini Gorice. To je izazvalo negativne reakcije među iseljenicima jer je Turel bio poznat kao „dobar patriota” i uživao ugled u jugoslavenskoj koloniji u Argentini. Kakve je posljedice vijest

\footnotetext{
39 Antunović je bio zaposlen u Argentini neprekidno od 1932. do 1948. u više poduzeća, pa je na temelju toga tražio određena prava preko Poslanstva. SR-AJ-25-172, „Antunović Petar, iseljenik-povratnik iz Argentine, raspored radnog mjesta itd.” od 20. 12. 1950.

40 SR-AJ-25-172, Pismo saveznoga inspektora rada Andrije Unkovića od 3. 11. 1950.

41 „Mornari na 'Partizanki' organizovali su dobar kulturno-prosvetni rad”, Politika, 3. 6. 1948., 5.

42 SR-AJ-25-66, „Izmjene i dopune u spisku druge grupe iseljenika-povratnika iz Argentine i Urugvaja” od 1.6. 1948., 3-4.

43 „Druga grupa iseljenika vraća se iz Argentine u domovinu”, Politika, 16. 6. 1948., 4.
} 
mogla imati na repatrijaciju govori i činjenica da je poslanik Pirc urgirao da se Turela „hitno pusti na slobodu”. Iz Ministarstva vanjskih poslova (MVP) podržali su taj zahtjev i zatražili hitno rješavanje toga pitanja u skladu sa željama Poslanstva. ${ }^{44}$

Uz suglasnost Poslanstva brod je u luci obišao i veći broj iseljenika, koji su ga mogli razgledati i razgovarati s onima koji putuju, čime se propagirala sama repatrijacija. Među putnicima drugoga transporta „Partizankom” bilo je najviše građevinskih radnika (107), zemljoradnika (69), metalskih radnika (41) i drvodjelaca (20). Pored radno sposobnih muškaraca bilo je 46 žena, 44 djece, ali i devet osoba nesposobnih za rad (slijepi i invalidi). Za taj transport puna cijena karte iznosila je 700 pesosa i nju je platilo 399 putnika. Cijena karte bila je jedinstvena i nije kao prije bilo podjele na prvu i drugu klasu. Poslanstvo je na temelju ekonomskoga stanja iseljenika odobrilo 80 besplatnih karata. ${ }^{45}$ Iako je broj odobrenih besplatnih karata bio manji nego prvi put, to je izazvalo nezadovoljstvo Odjeljenja za iseljenike u Jugoslaviji, čiji je načelnik Stjepan Lojen zaključio da su mnogi povratnici iz Argentine koji su putovali besplatno donijeli sa sobom veće svote novca. On je naglasio da se ubuduće za besplatan prijevoz računaju samo „siromašni povratnici koji se odmah uključuju u privredu". ${ }^{46}$

Prema podacima dostavljenim tisku, nacionalna struktura drugoga transporta bila je sljedeća: „251 Hrvat, 74 Istranina, 32 Srbina, 35 Makedonaca, 42 Bugarina, 24 Crnogorca, 9 iz Bosne i Hercegovine, 18 Čeha, 18 Mađara, 4 Albanaca i drugi." ${ }^{\prime 7}$ Zanimljivo je da na popisu nema Slovenaca, nego postoji termin „Istrani”, što samo po sebi ne govori koje su nacionalnosti bili povratnici koji su se vraćali u Istru.

Spomenuti Lojen bio je i na čelu delegacije koja je dočekala „Partizanku” u blizini Splita. Konstatirano je da je tijekom puta bilo više smrtnih slučajeva starijih putnika, a trojica su teško bolesna ležala u brodskoj bolnici. Oni su po dolasku smješteni u splitsku bolnicu. Brod je inače stigao u splitsku luku 18 . lipnja, dakle dvadesetoga dana od polaska iz Buenos Airesa. Dio iseljenika tu je napustio „Partizanku” zajedno sa strancima, a oni kojima je cilj bila Slovenija, Istra i sjeverno Hrvatsko primorje krenuli su dalje brodom za Rijeku. Zabilježeno je da su organi carine, i pored drukčijih uputa centrale u Beogradu,

44 SR-AJ-25-66, „Hapšenje iseljenika povratnika Turel Srećka” od 13. 5. 1948.

45 Ukupan prihod od karata drugoga transporta iznosio je 304.850 argentinskih pesosa, što je bilo nekih 25.000 više nego prvi put. Razlika je dolazila od jedinstvene cijene karata, pa je mnogo veći broj ljudi platio višu cijenu. SR-AJ-25-66, „Izmjene i dopune u spisku druge grupe iseljenika-povratnika iz Argentine i Urugvaja” od 1. 6. 1948., 4-5.

46 SR-AJ-25-66, Odgovor Poslanstvu u Rio de Žaneiru na depešu Pov.br 196 od 28. 6. 1948.

47 „Druga grupa iseljenika doputovala je juče Južne iz Amerike u Split”, Politika, 19. 6. 1948., 4. 
odvajali pakete koji su bili namijenjeni za dar rodbini iseljenika i tražili da se ocarine, što je izazivalo negodovanje povratnika. ${ }^{48}$

Među putnicima je bila i jedna poljoprivredna zadruga sa dvadeset članova koja je tražila kolektivni posjed u Jugoslaviji. Radilo se o bivšim zakupcima koji su se vraćali kući. Prema podacima Poslanstva koje je iznio v. d. načelnika konzularnoga odjeljenja u Buenos Airesu Kovačević, zadruga je raspolagala kapitalom od 21.000 pesosa. ${ }^{49}$ Zanimljivo je da su među putnicima drugoga transporta bili bugarska glumica Andrijana Budevska, koju su dočekali savjetnik i ataše bugarskoga veleposlanstva, i argentinski novinar Oscar Ares iz lista La Hora, koji je trebao postati specijalni dopisnik iz Jugoslavije. ${ }^{50}$

Inače, „Partizanka” je na putu od Jugoslavije do Argentine služila kao prijevozno sredstvo za ljude iz Europe, prije svega iz Italije i Francuske, do Južne Amerike. Tako je tijekom ljeta 1948. u povratku iz Genove i Marseillea povezeno oko 600 putnika. Među njima je pored Talijana bilo i Poljaka, Židova i Čeha. ${ }^{51}$ Bilo je slučajeva i da su se delegacije iseljenika vraćale nakon informiranja o mogućnostima osnivanja vlastitih zadruga u Jugoslaviji. Već prvim transportom u zemlju su stigla dva delegata radi priprema za osnivanje ribarske zadruge „Biser”. Prvi dojam bio je negativan jer su predstavnici iseljenika shvatili da neće moći ostvariti svoju zamisao zbog propisa da $90 \%$ zadrugara mora raditi u zadruzi, što s obzirom na veliki broj starijih iseljenika koji su htjeli investirati svoj novac u projekt nije izgledalo moguće. Konzularno odjeljenje Poslanstva u Buenos Airesu reagiralo je u nadi da se može naći neko rješenje za to pitanje, vjerojatno plašeći se da taj slučaj može negativno utjecati na daljnju repatrijaciju..$^{52}$

Treći transport razlikovao se od ostalih jer je imao fokus na Brazil. On je krenuo iz Buenos Airesa i Santosa krajem srpnja 1948. i prevozio 644 iseljenika, od čega 601 iz Brazila i 43 iz Argentine. ${ }^{53}$ Većina povratnika bila je podrijetlom iz Dalmacije. Iako je ta repatrijacija provedena nakon Rezolucije Informbiroa, ona nije imala većih posljedica na odaziv iseljenika jer nije, za razliku od slučaja Argentine, dovela do većega osipanja jugoslavenskih udruženja u Brazilu, čiji su iseljenici činili preko $90 \%$ trećega transporta.

Od pristiglih povratnika njih 74 otišlo je svojim kućama jer se radilo uglavnom o starijim ljudima narušenoga zdravlja. Od ostalih je bilo najviše

48 SR-AJ-25-66, „Putni izvještaj” koji je sastavio Šime Kovačić od 26. 6. 1948.

49 SR-AJ-25-66, „Povratnici iz Južne Amerike” od 28. 4. 1948.

50 „Druga grupa iseljenika doputovala je juče Južne iz Amerike u Split”, Politika, 19. 6. 1948., 4.

51 SR-AJ-25-66, „Izvještaj Ministarstvu rada o Trećoj grupi povratnika iz Južno-Američkih država”, 1 .

52 SR-AJ-25-66, „Akcija iseljenika iz Južne Amerike za osnivanje zadruge 'Biser”” od 24. 6. 1948.

53 SR-DAMSP-PA, 1949, Argentina, f. 6, d. 9, s. 49700, „Referat o jugoslovenskim iseljenicima u Južnoj Americi”, 17. 
tekstilaca (131) i mehaničara (25), a drugi su bili različitih zanimanja. Zanimljivo je da je više od polovice povratnika iz trećega transporta „Partizankom”, njih 381, potjecalo iz Blata, a 109 iz Vele Luke s otoka Korčule. Prilikom analize puta primijećeno je da se održava previše predavanja koja nisu „aktuelna za vreme putovanja” jer se radi o „teškim temama” koje nije moguće objasniti u kratkim predavanjima. To se osobito odnosilo na povratnike koji „tri dana boluju od morske bolesti i leže po palubama, kao snoplje pokošenog žita”. Problem je nastajao i prilikom konverzije novca jer su povratnici u Južnoj Americi kupovali dolare, što ih je koštalo 60 do 70 dinara, a pri povratku u Jugoslaviju ti su im dolari otkupljivani po cijeni od 50 dinara. To je, logično, izazvalo nezadovoljstvo. ${ }^{54}$

Nakon Rezolucije Informbiroa počelo je prilično komešanje među jugoslavenskom emigracijom u Argentini, što se itekako odrazilo na repatrijaciju i privremeno ju prekinulo. Većina udruženja jugoslavenskih iseljenika podržala je Rezoluciju, kao i Komunistička partija Argentine, što je također bilo važno za njihove stavove. Već tijekom kolovoza, imajući u vidu informaciju o malom broju prijavljenih, počela je akcija da se prijevoz učini ekonomski što isplativijim. Odlučeno je da se stranim putnicima cijena prijevoza podigne na 850 pesosa. Ipak, to nije prošlo lako jer je ustanovljeno da talijanske kompanije strancima naplaćuju 800 pesosa prijevoz do Genove, što je „Partizanku” činilo neatraktivnom. ${ }^{55}$

Tako je posljednji transport 1948. bio najmalobrojniji. Četvrti transport „Partizankom” počeo je 16. rujna i u njemu je bilo 275 povratnika, od čega 257 iz Argentine, a ostali su bili iz Čilea, Urugvaja i Bolivije. Tijekom ljeta, prije transporta, informacije su bile različite. Poslanstvo je navodilo mogućnost putovanja preko 300 ljudi, pa u jednom trenutku i više od 500. Ipak, to se iz spomenutih razloga nije dogodilo. Među onima koji su stvarno otputovali bila su 242 muškarca, 23 žene i 10 djece. Najviše je bilo poljoprivrednih (92) i građevinskih (60) radnika, a ostalih mnogo manje. Za povratnike je ostala cijena od 700 pesosa, a nju je platilo 179 putnika. Ostali su ili plaćali pola cijene, u prvom redu djeca, ili putovali besplatno. Strani putnici platili su dogovorenu cijenu od 850 pesosa, među njima Bugari, Mađari i Česi, a zanimljivo je da su članovi veleposlanstva Sovjetskoga Saveza u Čileu, njih 28, platili cijenu od 1.500 pesosa. ${ }^{56}$

\footnotetext{
54 SR-AJ-25-66, „Izvještaj Ministarstvu rada o Trećoj grupi povratnika iz Južno-Američkih drŽava", 1 .

55 SR-AJ-25-66, „Repatrijacija iz Argentine, i drugih zemalja J. Amerike” od 30. 8. 1948.

56 SR-AJ-25-66, „Repatrijacija iz Argentine i Urugvaja u septembru 1948 godine” od 20. 9. 1948., $1-2$.
} 
I za taj transport organizirana je komisija za prihvat i ona se početkom listopada sastala u Splitu, a izvještaj je podnio načelnik Odjeljenja za iseljenike Lojen. Povratnike su pozdravili i predstavnik Narodne fronte i povjerenik Odjeljenja rada. Priča o radu na ostvarenju „Titovog Petogodišnjeg plana” nije izostala ni toga puta. Dio putnika je iskrcan, a dio je kao i u prethodnim slučajevima nastavio putovanje do Rijeke. S obzirom na okolnosti oko organizacije transporta i njegove brojnosti, četvrti transport očekivano je ocijenjen kao najslabiji jer se većinom radilo o starim ljudima koji se nisu mogli uključiti u privredu. Od svih povratnika uključeno je samo 68 osoba, i to 23 u građevinarstvo, devet u tešku industriju, sedam u laku industriju, četiri u poljoprivredu, a ostali u druge poslove. Kako nije bilo mogućnosti da im se osigura smještaj u većim gradovima, dio radnika odlučio je otići rodbini i prijateljima, što je dodatno utjecalo na mali broj povratnika iz toga transporta koji je uključen u privredu. ${ }^{57}$

U izjavama koje su povratnici dali prilično su otvoreno nagovještavali ono s čim su se suočili u Argentini nakon Rezolucije Informbiroa. Predsjednica odbora četvrte grupe iseljenika povratnika Nada Pejaković rekla je: „Vratili smo se premda su nas odvraćali razni neprijatelji Titove Jugoslavije, jer nismo verovali u laži i klevete koje su se u poslednje vreme sručile naše narode, našu Partiju i druga Tita." Trenutačnu borbu države i Partije usporedila je s Neretvom i Kozarom. ${ }^{58}$ Upadljivo je da nisu konkretno imenovani neprijatelji, što je imalo veze s tadašnjom fazom u sukobu s Informbiroom, kad se još uvijek izbjegavala izravna konfrontacija. S druge strane javno upozoravanje na probleme s argentinskim vlastima također se smatralo kontraproduktivnim.

U spominjanoj publikaciji iz 1953. nalazimo i peti transport „Partizankom”, kojim je, kako se kaže, iz Argentine pristiglo 27 iseljenika povratnika. Kao datum pristanka broda na jugoslavenski teritorij naveden je 28. studenoga. ${ }^{59} \mathrm{U}$ pregledanim izvorima nismo našli detaljnije podatke o tom transportu, ali s obzirom na mali broj povratnika iz Južne Amerike, on ne mijenja generalni zaključak ni uočene trendove.

Što se tiče transporta tijekom 1948., možemo zaključiti da je u Jugoslaviju pristiglo između 1600 i 1700 iseljenika povratnika iz Argentine i Urugvaja te nešto više od 600 iz ostalih država Južne Amerike, prije svega Brazila. Po nekim analizama, među putnicima je bilo oko 70 \% Hrvata, 15 \% Srba i 5 \% Slovenaca, a ostatak je otpadao na druge narode i one kojima je Jugoslavija bila

\footnotetext{
57 SR-AJ-25-66, „Izvještaj o prihvatanju iseljenika-povratnika koji su stigli brodom 'Partizanka' 6 oktobra 1948 iz Južne Amerike” od 16. 10. 1948.

58 „Četvrta grupa naših iseljenika vratila se iz Južne Amerike”, Politika, 7. 10. 1948., 2.

59 ŠEGVIĆ, Povratak jugoslovenske ekonomske emigracije, 27.
} 
samo prolazna stanica prema drugim zemljama. ${ }^{60}$ Spomenuta 1948 . bila je i vrhunac organiziranoga povratka u Jugoslaviju. Te je godine zabilježeno čak deset kružnih putovanja preko oceana „Partizanke” i „Radnika”. Organizirani prijevoz iseljenika uskoro će biti znatno umanjen, a poslije faktički potpuno obustavljen. Posljednji veliki organizirani transport jugoslavenskih iseljenika bio je onaj u ožujku 1949. iz Australije, koji je obavila „Partizanka”.

Iako je 1948. godina bila vrhunac poslijeratne repatrijacije jugoslavenskih državljana, službeni organi FNRJ očekivali su mnogo veći priljev iseljenika. U jednoj kasnijoj analizi ustanovljena su četiri glavna razloga zašto se to nije dogodilo. Prvi je vezan za vanjskopolitičku situaciju, prije svega pritisak Sovjetskoga Saveza i Rezoluciju Informbiroa. To se, kao što smo vidjeli, posebno odrazilo na iseljenike u Argentini. Drugi razlog je razvoj privrede u zemljama u kojima su boravili jugoslavenski iseljenici, osobito grana u kojima su bili zaposleni. Preostala dva razloga bila su vezana za subjektivni faktor, odnosno aktivnost predstavnika FNRJ i u inozemstvu i u zemlji. Navodila se nedovoljna angažiranost jugoslavenskih diplomatskih predstavništava i njihova „nepotrebna propaganda sa nestvarnim obećanjima o prihvatu i uslovima života po dolasku u FNRJ". ${ }^{61} \mathrm{~S}$ druge strane u zemlji prihvat iseljenika nije bio dobro organiziran, što se posebno vidjelo kad se broj povratnika povećao.

Broj repatriranih 1949. bio je bitno manji nego prethodne dvije godine. Organizirana su dva transporta brodom „Radnik”, u ožujku i studenom, i njima se vratilo 21, odnosno 149 iseljenika. Radilo se o ukupno 199 osoba, računajući i one koji su se vratili u vlastitoj organizaciji. Postojao je niz problema vezan uz te transporte. Za prvi je bilo predviđeno samo devet mjesta za Argentinu, što je dovelo do problema jer se prijavilo više ljudi. Na kraju je ukrcana 21 osoba, od kojih su oni prekobrojni navedeni kao članovi posade. Problem s drugim transportom bilo je njegovo kašnjenje (više od mjesec dana), što je izazvalo probleme iseljenicima iz unutrašnjosti, koji su se morali snalaziti u Buenos Airesu i trošiti sredstva koja su ponijeli. Naime, predviđeni datum polaska bio je 30. rujna, a brod je krenuo tek 12. studenog. ${ }^{62}$

O točnom broju ljudi u prvom transportu „Radnikom” ima određenih neslaganja. Izvještaj Jugoslavenske linijske plovidbe govori o 16 povratnika pozivajući se na „brzojav Zapovjedništva” broda. On donosi i nacionalni sastav iseljenika povratnika, među kojima je bilo 12 Hrvata, dva Crnogorca i po jedan Slovenac i Makedonac, odnosno 14 muških i dvije ženske osobe. Svih 16 putnika iskrcano je u Splitu, a samo su se dvojica, jedan stolar i jedan drvodje-

60 Slavko SUZIĆ, „Emigrantski brod Partizanka”, Sušačka revija, 2008., br. 60, 25.

${ }_{61}$ ŠEGVIĆ, Povratak jugoslovenske ekonomske emigracije, 29. Vidi i: KARAKAŠ OBRADOV, Novi mozaici nacija, 111.

62 SR-DAMSP-PA, 1950, Argentina, f. 7, d. 15, s. 43770, „Godišnji konzularni izveštaj za 1949 g.”, 12. 
lja, prijavili za rad nakon mjesec dana boravka kod kuće. ${ }^{63}$ Bilo kako bilo, jasno je da je repatrijacija 1949. bila znatno manja i što se tiče broja ljudi i pogotovo što se tiče onih koji su nakon povratka uključeni u privredu FNRJ. Što se tiče drugoga transporta 1949., Ministarstvo rada NR Hrvatske bilo je spremno prihvatiti 24 iseljenika povratnika koji su pripadali njezinu teritoriju. Sastav te grupe bio je raznorodan, a najviše je bilo zemljoradnika (7). ${ }^{64}$

Drugi transport „Radnikom” stigao je u splitsku luku 12. prosinca. Priređen je svečani doček na kojem su govorili predstavnici vlasti, Gradskoga odbora Splita i ministar rada Vlade NR Hrvatske Alojz Valečić, kao i predstavnik iseljenika. I tada su se između redova mogli iščitati problemi s kojima se i ta organizacija transporta suočavala. Uime iseljenika govorio je Ignjatije Balog, koji je nakon zahvaljivanja na primanju i izražavanja spremnosti da se pomogne u izgradnji socijalizma uzviknuo da ih nikakve klevete nisu mogle zadržati od povratka u domovinu, pa neće ni njihovu braću, ostale iseljenike. ${ }^{65}$ Jasan izbor koji je od svega što je rečeno objavio Tanjug, a prenio partijski list Borba, dovoljno govori.

Kao što smo rekli, repatrijacija je dovodila do problema u odnosima dviju zemalja. U svibnju je otpravnik poslova Argentine Tristani prosvjedovao spominjući argentinske državljane koji su došli u posjet rođacima, a uskraćuje im se pravo na povratak. ${ }^{66}$ Već nakon prvoga transporta početkom lipnja 1948. uslijedilo je i pismo MVP-u vezano za državljane te zemlje koji su doputovali u Jugoslaviju. Izneseno je da se radi o više slučajeva gdje su iseljenici mislili da se radi o posjetu u trajanju od nekoliko mjeseci, a ne o potpunom povratku. U prilog tome govorila je i činjenica da je jugoslavensko poslanstvo izdalo iseljenicima ulazno-izlazne vize. Otpravnik poslova zaključio je da je odluka o povratku donesena „uglavnom na osnovu žive propagande koju je razvilo jugoslovensko poslanstvo u Buenos Airesu”.

Posebno su naglašena dva slučaja, Luisa Grgurića i Johana Pamića, nastanjenih u Zagrebu, odnosno Puli. Grgurić je, kako se navodi, pripremao povratak u Argentinu za sebe, ženu i sina i za to pribavio potrebne vize, ali mu je u Ministarstvu unutrašnjih poslova Hrvatske rečeno da se te isprave ne mogu priznati. Pamićev slučaj smatran je još težim jer se radilo o čovjeku koji je bio argentinski državljanin zajedno sa svoje tri kćeri i dva sina, a po navodima je

\footnotetext{
63 SR-AJ-25-172, „Pb. Radnik - Put. br.1/49 povratno iz Buenos Airesa” od 22. 3. 1949.

64 SR-AJ-25-172, „Repatrijacija iz Argentine” od 18. 11. 1950., Pismo Andrije Unkovića, saveznoga inspektora rada.

65 „Brod 'Radnik' sa petom grupom naših iseljenika iz Urugvaja i Australije stigao u splitsku luku”, Borba, 16. 12. 1949., 4. Očito se radi u pogrešci u naslovu, gdje se umjesto Argentine spominje Australija.

${ }_{66}$ SR-AJ-836-KMJ, I-3-b/57, „Zabeleška o razgovoru druga Vlahova s otpravnikom poslova Argentinskog poslanstva u prisustvu načelnika MIP druga Price, na dan 22 maja 1948”.
} 
jedino supruga Franciska bila jugoslavenska državljanka. Argentinski poslanik uputio je zahtjev da se ta dva slučaja riješe u skladu sa željom imenovanih, a oni i njihove obitelji zajedno s novcem koji im je deponiran u Narodnoj banci u Zagrebu vrate u Buenos Aires. ${ }^{67}$

Argentinski otpravnik poslova Tristani i u srpnju 1948. posjetio je jugoslavenski MVP zbog spomenutih slučajeva, tvrdeći da se Pamiću i Grguriću ne dopušta izlazak iz Jugoslavije. Primio ga je predstavnik Ministarstva Gustav Vlahov. Tristani je tvrdio da jedan od spomenute dvojice ima ugovor s argentinskom tvrtkom koja mu je dala dopust od šest mjeseci i očekuje da se vrati na posao. Vlahov se izgovarao da je MVP postupio vezano uz taj problem, ali je i dalje u iščekivanju odgovora. Argentinski otpravnik poslova tom je prilikom donio novi popis od 12 osoba za koje je tvrdio da se žele vratiti u Argentinu. Zanimljivo je da je Tristani, vjerojatno radi relaksacije cijele stvari, čestitao na stavu jugoslavenske vlade nakon Rezolucije Informbiroa, dodajući da ona „zadivljuje čitav svet”. S druge strane veoma je indikativna napomena koju je Vlahov ostavio na kraju dokumenta, gdje je krivnju za situaciju svalio na Poslanstvo u Buenos Airesu, koje je izdalo ulazno-izlaznu vizu i na taj način „postavilo dotično lice u položaj turiste”. Na kraju je zaključio da je danas jugoslavenski „stav vrlo težak, kad mi nećemo da pustimo da izađu ovi ljudi”. ${ }^{68}$ Nedostatak izvora nije nam omogućio da ispratimo rješenje tih slučajeva, ali je nesporno da su oni negativno utjecali na odnose dviju država, kao i spomenuta živa propagandna aktivnost u cilju repatrijacije jugoslavenskoga poslanstva u Buenos Airesu.

Vezano za reemigraciju, službeni podaci FNRJ iz Ministarstva unutrašnjih poslova govore da su se u Argentinu 1949. i 1950. vratile samo četiri osobe. Zanimljivo je da je taj broj za Brazil nešto veći - 24. S obzirom na to da je ukupan broj reemigranih iz FNRJ 1946. - 1951. blizu tisuću, možemo zaključiti da je bilo još slučajeva povratka u Argentinu, ali je njihov točan broj teško ustanoviti. ${ }^{69}$ Razlozi za ponovno napuštanje Jugoslavije bili su brojni: nesnalaženje u uvjetima koji su ih dočekali, razlika između proklamiranoga i stvarnosti, nedostatak i neblagovremenost pomoći lokalnih organa, ali i slučajevi gdje je jedan od bračnih drugova bio strani državljanin, što je utjecalo na kasniju odluku o ostanku/povratku.

Kakav je bio odnos određenih peronističkih krugova prema repatrijaciji govori i pisanje lista Democracia, bliskog Evi Perón, koje su zabilježili jugosla-

\footnotetext{
67 SR-AJ-25-66, Prijevod pisma argentinskoga poslanika u Beogradu od 5. 6. 1948.

68 SR-AJ-836-KMJ, I-3-b/57, „Zabeleška o razgovoru druga Vlahova s argentinskim poslanikom na dan 3 jula 1948 u prisustvu druga Bardelića”.

69 ŠEGVIĆ, Povratak jugoslovenske ekonomske emigracije, 61.
} 
venski diplomati. ${ }^{70}$ Glavne teze u navedenom članku bile su: „Argentina neće dopustiti političke manjine na svojoj teritoriji. Deca useljenika su Argentinci, i oni koji se s time ne slažu mogu izaći iz zemlje” i „Argentina ne dopušta delegiranje suverenosti, te se stranim diplomatima ne dopušta zaštita interesa vlastitih državljana." Taj članak smatran je indikacijom koje bi korake argentinska vlada mogla poduzeti ako se odnosi pogoršaju. ${ }^{71}$

Vezano za repatrijaciju javio se još jedan problem, a to je bilo različito tretiranje iseljenika s dvojnim državljanstvom, što se posebno odnosilo na djecu jugoslavenskih iseljenika koja su rođena na teritoriju Argentine, dakle po argentinskim zakonima bili su njihovi državljani. Ministarstvo vanjskih poslova FNRJ, čini se reagirajući na ponašanje argentinskoga, u veljači 1949. dalo je direktivu Poslanstvu da ne izdaje vize osobama s dvojnim državljanstvom. Čak je zahtijevalo da se dotad izdane vize pravdaju greškom Poslanstva. Svjesni problema koje bi izazvala primjena te naredbe, Poslanstvo ju je odbilo provesti znajući da bi ona blokirala repatrijaciju jer bi se javili slučajevi da roditelji dobiju ulaznu vizu za Jugoslaviju, a djeca ne. Poslanstvo je ignoriralo stav Ministarstva i za oba transporta „Radnikom” izdalo ulazne vize osobama s dvojnim, jugoslavensko-argentinskim državljanstvom. Nakon toga upućena je molba da se proklamirani stav razmotri, upozoravajući na negativne posljedice njegova provođenja u budućnosti. ${ }^{72}$ Uvidom u arhivsku građu možemo zaključiti da zbog svih iznesenih razloga od početka pedesetih godina organizirane repatrijacije više nije bilo.

Jasno je da su se mnogi stariji povratnici odlučili vratiti vođeni nostalgijom za „starim krajem”, a neke mlađe privukla je stvarnost koju su udruženje jugoslavenske emigracije i samo Poslanstvo u Buenos Airesu propagandno obojili. Teško da je itko uistinu mogao znati što ih očekuje kad se vrate u Jugoslaviju. Bila je to ratom razrušena zemlja, koja se ponovno gradila, pod novim režimom koji se utvrđivao i koji se u tim trenucima suočavao s velikom vanjskom i unutarnjom krizom izazvanom razlazom sa Sovjetskim Savezom i njegovim satelitima. Dodatni problem za iseljenike bio je, kao što smo vidjeli, što je znatan dio njih bio siromašan, pa im je snalaženje bilo još teže. Problemi kao što su dugo čekanje broda i troškovi koji su to pratili ili konverzija valute po nepovoljnom tečaju samo su doprinijeli njihovu osiromašenju. Naravno, u povoljnijem položaju bili su oni koji su se imali kamo vratiti i nisu počinjali od početka, ali oni su bili u manjini.

\footnotetext{
70 U spomenutom listu pisao je i Juan Perón pod pseudonimom Descartes. LUNA, Kratka istorija Argentinaca, 179.

71 SR-AJ-25-66, „Izvještaj iz Argentine”, bez datuma, vjerojatno s kraja 1947. godine.

72 SR-DAMSP-PA, 1950, Argentina, f. 7, d. 15, s. 43770, „Godišnji konzularni izveštaj za 1949 g.”, 8.
} 
U sljedećoj tablici možemo vidjeti službene podatke vezane za broj iseljenika povratnika iz Argentine u prvim godinama nakon Drugoga svjetskog rata.

Ukupan broj iseljenika povratnika iz Argentine (1945. - 1951.)

\begin{tabular}{|l|r|}
\hline Godina & Broj repatriranih \\
\hline 1945. & 5 \\
\hline 1946. & 22 \\
\hline 1947. & 178 \\
\hline 1948. & 1457 \\
\hline 1949. & 29 \\
\hline 1950. & 47 \\
\hline 1951. & 10 \\
\hline Ukupno & 1748 \\
\hline
\end{tabular}

Izvor: Podaci ulazne registracije i službeni izvještaj. Navedeno prema podacima iz: Šegvić, Povratak jugoslovenske ekonomske emigracije, 16.

Prema službenim podacima, od ukupnoga broja repatriranih u Jugoslaviji od 1945. do 1951. iz Argentine ih je pristiglo 1748, što čini 10,84 \% od ukupnoga broja jugoslavenskih državljana povratnika. Ispred Argentine u tom je periodu po broju povratnika bila jedino Francuska sa 3914, a iza je ostala Kanada sa 1727 povratnika. ${ }^{73}$ Vidimo i ono što se može zaključiti iz iznesenoga - da je 1948. bila ključna godina i da se samo tijekom nje vratilo više od 83 \% povratnika iz Argentine u prvim poslijeratnim godinama.

Što se tiče iseljenika koji su ostali u Argentini, pedesetih godina primijećen je i jedan važan proces, a to je da se dio političke emigracije s vremenom pretvarao u ekonomsku. To se događalo dijelom pod utjecajem starije ekonomske emigracije, dijelom zato što su neki shvaćali da njihovi politički ciljevi nisu tako lako dostižni, pa su se sve više okretali svakodnevici života u novoj domovini, odnosno borbi za osiguranje boljega života sebi i vlastitoj obitelji. Njihova situacija ni sredinom pedesetih nije se mnogo popravila, pa je poslanik Slavoljub Petrović vidio „kulturnopolitičku zaostalost” većine iseljenika, „teško nasleđe” prošlosti i posljedice teških životnih uvjeta. Vezano za omladinu situacija je prikazana još lošijom jer je konstatirano da se oni „manje ili više” ne osjećaju Jugoslavenima i najveći broj više ih ne govori jezik, nego nastoje naći svoje mjesto $u$ argentinskom društvu. ${ }^{74}$

${ }_{3}$ ŠEGVIĆ, Povratak jugoslovenske ekonomske emigracije, 16.

74 SR-DAMSP-PA, 1956, Argentina, f. 3, d. 10, s. 424146, „Odnosi FNRJ - Argentina”, 5-6. 
U najkraćem, pitanje jugoslavenskih iseljenika u Argentini bilo je jedno od najvažnijih u odnosima dviju država. Krajem četrdesetih godina osobito postoji suprotstavljeni interes dviju zemalja jer su obje željele privući kvalificiranu radnu snagu. S obzirom na to da se radilo isključivo o ljudima koji su živjeli u Argentini, FNRJ ih je željela privući da se vrate, a Argentinci su ih pokušavali zadržati. Takva situacija odrazila se na pogoršanje međusobnih odnosa i povećanje nepovjerenja između službenih organa. 


\section{Arhivski izvori}

SR-AJ-25: Srbija, Arhiv Jugoslavije, Beograd, fond 25, Ministarstvo rada Vlade FNRJ.

SR-AJ-836-KMJ: Srbija, Arhiv Jugoslavije, Beograd, fond 836, Kabinet maršala Jugoslavije.

SR-DAMSP-PA: Srbija, Diplomatski arhiv Ministarstva spoljnih poslova Republike Srbije, Beograd, Politička arhiva: Argentina, Južna Amerika.

\section{Objavljeni izvori}

IV Censo General de la Nación, Censo de Población, Tomo I. Buenos Aires: Dirección Nacional del Servicio Estadístico, 1947.

Ministerio de Relaciones Exteriores, Comercio Internacional y Culto. Biblioteca Digital de Tratados, Acuerdo Estableciendo Relaciones Diplomáticas y Comerciales entre la República Argentina y la República Federativa Popular de Yugoslavia, Ley $\mathrm{n}^{\circ}$ 13.519. Pristup ostvaren 9. 6. 2020. https://tratados.cancilleria.gob.ar/.

\section{Literatura}

ANTIĆ, Ljubomir. Naše iseljeništvo u Južnoj Americi i stvaranje jugoslavenske države. Zagreb: Školska knjiga, 1987.

Borba (Beograd), 1948-1949.

DERADO, Klement; ČIZMIĆ, Ivan. Iseljenici otoka Brača. Zagreb; Brač: SIZ za kulturu općine Brač, 1982.

HOLJEVAC, Većeslav. Hrvati izvan domovine. Zagreb: Matica hrvatska, 1967.

KARAKAŠ OBRADOV, Marica. Novi mozaici nacija u „novim poredcima”. Migracije stanovništva na hrvatskom području tijekom Drugoga svjetskog rata i poraća. Zagreb: Hrvatski institut za povijest, 2014.

LUNA, Feliks. Kratka istorija Argentinaca. Novi Sad: Akademska knjiga, 2015.

PINO, Adriano; CINGOLANI, Giorgio. Nationalism and Terror. Ante Pavelić and Ustasha Terrorism from Fascism to the Cold War. Budapest; New York: CEU Press, 2018.

Politika (Beograd), 1948.

SIMIĆ, Bojan. „Srpska emigracija u Argentini u prvoj deceniji nakon Drugog svetskog rata - prilog istraživanju problema”. Godišnjak za društvenu istoriju XXVI (2019), br. 2: 55-68.

Sušačka revija (Sušak), 2008.

ŠEGVIĆ, Vesela. Povratak jugoslovenske ekonomske emigracije: 1945-1951. Beograd: Rad, 1953. 


\section{SUMMARY}

\section{A Long Way Home - The Return of Yugoslav Immigrants from Argentina (1946-1951)}

Diplomatic, consular and economic relations between the Federal People's Republic of Yugoslavia and the Republic of Argentina were established on 16 September 1946. The agreement was signed by General Ljubo Ilić, chief of the Yugoslav diplomatic mission in South America, and Juan Atilion Bramuglia, Argentinian Minister of Foreign Affairs and Religion. In the first decade after World War II, the two states had some open problems and unresolved issues such as the question of commercial agreements, Yugoslav political emigration in Argentina, especially the Ustasha movement, Argentine nationalised property in Yugoslavia, visas for entering Argentina etc.

Following World War II, Argentina became the country with the most emigrants of Yugoslav origin in the entire Latin America. The major part of those were Croats and Slovenes, while emigrants from Montenegro and Serbia made up a smaller proportion. The issue of Yugoslav immigrants in Argentina was of the greatest importance in the relations between two countries. In the late 1940s, the interests of Yugoslavia and Argentina in this matter were opposed. Both sides wanted to use a qualified work force for building their own country. Yugoslavia tried to recruit immigrants to come back and take part in fulfilment of the Five-Year Plan established in 1947. Argentina on the other hand, wanted to keep able-bodied people for building its own industry. The Yugoslav government sent ships for immigrants and organised housing and jobs for them upon their return. The majority of them were construction, agriculture, and textile workers. The peak of the repatriation was 1948, when $83 \%$ of Yugoslav immigrants returned from Argentina.

There was another problem, and that was the different treatment of immigrants with dual citizenship, which especially referred to the children of Yugoslav immigrants who were born on Argentine soil. According the law, they were Argentine citizens, but Yugoslav authorities still thought of them as their own. According to official data, of all the people to return in Yugoslavia in the 1946-51 period, a total of 1,748 arrived from Argentina, which was $10.84 \%$ of the total number of returning Yugoslav citizens. Only France was ahead of Argentina in this period in terms of numbers of returns, with 3,914, while Canada was behind, with 1,727.

Key words: immigration; South America; FPR Yugoslavia; Republic of Argentina; repatriation 